\title{
Medieval perspectives in Europe: Oral culture and bodily practices
}

1. Oral culture in the Middle Ages

2. Bodily signs: Structure and semantics

3. Areas of application

4. References

\begin{abstract}
Prior to the invention of book printing, Western culture had no efficient storage medium that served to unburden human memory. Instead of writing a mnemotechnics based on the visual perception of bodily movements, took over the functions of orienting, identifying, and stabilizing the social order in the medieval period. In medieval instructions on ecclesiastic and secular norms of behavior, the categorization of the most wide-spread and relevant bodily practices was ordered according to the various functions of the body parts involved, such as neck, back, and knee muscles, arms, hands, lips, and facial muscles. Naturally, such a system of signifiers (like the prostration, the genuflection with inclined body, the genuflection with erect body, bowing to the waist, bowing to the chest, the foot kiss, the knee kiss, the shoulder kiss, the hand kiss, etc.) which will be reconstructed here on the basis of various source corpora, could not encompass all the motion sequences that took place in the context of different interactions. Nevertheless, it has proven useful to treat socially meaningful actions as communicative acts within the contexts of 1) religion, 2) law, 3) ceremonial and 4) etiquette.
\end{abstract}

\section{Oral culture in the Middle Ages}

Prior to the invention of book printing, Western culture had no efficient storage medium that served to unburden human memory. Based on this observation, Walter Ong constructed his theory of orality, according to which orally communicating peoples know only what they can bear in memory. According to Ong (1982), oral culture is a form of culture in which "no one can 'look up' anything." Its members "perceive words as sounds" that exist only in the moment of their emergence. Primary orality is thus organized "situationally rather than abstractly" (Ong 1982: 11; McLuhan 1960: 207). As soon as one attempts to grasp Ong's notion of orality through theories of cognition and communication, however, one invariably encounters a series of inconsistencies.

To begin with, Ong's distinction between "literate" and "pre-literate" applies to material types of media, whereas his dichotomy of "seeing" vs. "hearing" refers to the nature of human channels of perception. It would be definitely a wrong assumption that our ancestors' sensuous intake capacities differed from ours. In the hierarchy of the channels of perception and communication, sight is accorded a leading role because it expands and defines the physiological and cognitive functions of other sensomotoric subsystems, such as hearing, taste, smell, and touch (Loenhoff 2001: 171). The eye, which enables such different functions as planning, programming, and geographic 
surveying, is the primary precondition for all cognition, control, and cultural semiosis. In the context of pre-literate culture, the hierarchy of modes of cognition was no different from that of other ages. In the Middle Ages, too, human cognitive processes were guided primarily by the eye. Instead of writing, however, a mnemotechnics based on the visual perception of bodily movements took over the functions of orienting, identifying, and stabilizing the social order in the medieval period.

Secondly, Ong's notion of "orality" narrows the context of communication insofar as it refers only to the exchange of information using language between a speaker and a recipient. Such a narrowed approach completely excludes from consideration the position of the body toward the addressee, for example, as well as the role of eye contact (or the lack thereof), openness of arms and legs, shoulder position, in other words, all those behavioral variables which always co-determine the course and character of communicative acts. In order to understand the specificity of oral culture in the Middle Ages, we must thus comprehend the structural and semantic relationship of verbal and non-verbal signs to one another and their meaning in the context of pre-literate communication.

\section{Bodily signs: Structure and semantics}

In what follows, the "sign" will be treated in accordance with general semiotic theory as the relationship between signifier and signified. If we define the signifier as the perceptible movement of a body part, the signified can be defined as the context-bound meaning of such a movement. The relationship of various signifiers to one another and to their signifieds is characterized by a number of peculiarities in the Middle Ages. In order to better determine them we will analyze late Roman (Alföldi 1935: 103 111) as well as Byzantine (De ceremoniis, 10th century) instructions for court ritual, early medieval instructions for ecclesiastic prayer practices, particularly those of Humbert de Romans, Petrus Cantor, and St. Dominic (Schmitt 1992: 274 304; Trexler 1987: 43), as well as descriptions of encounters between medieval diplomats (Voss 1987: 134 136).

In medieval instructions on ecclesiastic and secular norms of behavior, the categorization of the most wide-spread and relevant bodily practices was ordered according to the various functions of the body parts involved, such as neck, back, and knee muscles, arms, hands, lips, and facial muscles. Naturally, such a system of signifiers, which will be reconstructed here on the basis of various source corpora, could not encompass all the motion sequences that took place in the context of different interactions. Nevertheless, it has proven useful to treat socially meaningful actions as communicative acts.

\subsection{According to body position}

The prostration (prostratio), i.e. lying prostrate on the ground, the lying prostration (prostratio venia)

\subsection{According to the function of the knee joints}

The genuflection (genuflexio)

(i) The genuflection with inclined body (genuflexio proclivis)

(ii) The genuflection with erect body (genuflexio recta) 
2.3. According to the function of the hip joints

Bowing (inclinatio)

(i) Bowing to the waist (inclinatio plena)

(ii) Bowing to the chest (inclinatio semiplena)

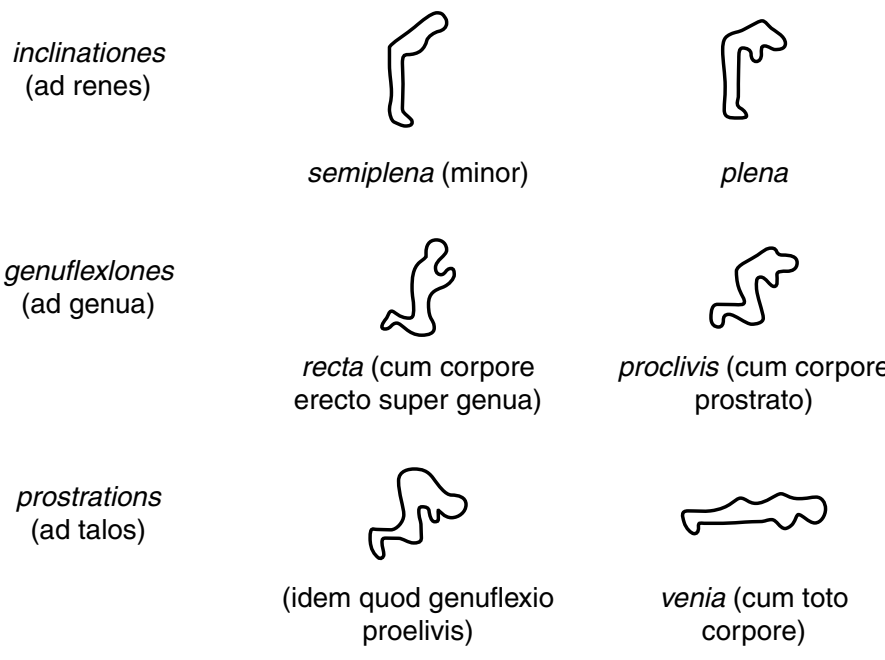

Fig. 23.1 Medieval practices of bowing

2.4. According to the function of the cervical joints

The head nod (capite nutare, nutus)

2.5. According to the function of the arm joints

The embrace (amplexus)

2.6. According to the function of the elbow joints

Greeting by hand

(i) The handshake (dextram dare, porrigere)

(ii) Removing one's hat, i.e. baring one's head (caput aperire)

(iii) Blowing a kiss (basia iactare)

\subsection{According to the function of the lips}

The kiss (osculum)

(i) The foot kiss (osculum pedum)

(ii) The knee kiss (osculum genuum) 
(iii) The shoulder kiss (osculum ulnae)

(iv) The hand kiss (osclum manui)

(v) The cheek and mouth kiss (osculum oris)

(vi) The forehead kiss (osculum frontis)

\subsection{According to the function of other facial muscles}

(i) Winking at someone (nictatio)

(ii) Raising one's eyebrows, etc.

The basic body techniques listed above can be subdivided into more complex categories. For instance, the term proskynesis was generally used to refer to the combination of the genuflection with a kiss on the feet, knees, or hand, or, somewhat less frequently, to a combination of bowing and kissing the corner of a garment or a hand. In regard to the nature of the relationship between signifier and signified, we can further distinguish between iconic vs. indexical and symmetric vs. asymmetrical bodily signs.

\subsection{Iconic vs. indexical bodily signs}

While iconic signs postulate a relationship of similarity between signifier (e.g. a portrait) and signified (a face), indexical signs presuppose a relationship between part and whole. Iconic bodily signs can be mastered without extensive schooling and are thus reproduced relatively easily. Their social reproduction is subject to the principle of analogy. A simple demonstration generally suffices to ensure the continued use of a given sign. The recognition of indexical signs, by contrast, relies on the human ability to construct causal and concessive relationships between a trait (e.g. smoke) and the entire context of traits (fire). This ability presupposes experience and is acquired over the course of more extensive training.

In the Middle Ages, the semiotic distinction between "iconic" and "indexical" was symbolically implemented in a storage medium accepted by the whole of society: the icon. Depicted on icons, techniques such as the genuflection or the bow possessed such exceptional potential for communal integration because they could be adopted by representatives of all social layers, as well as by foreign migrants, without much effort. In situations of multilingual oral communication, the function of social orientation was shifted primarily to iconic bodily movements. Consequently, in the context of religious and ceremonial communication, nonverbal sign systems were to some extent more important than verbal expressions. The rule of silence (silentium), which increased the believer's focus on the optical perception of body movements, was therefore an important component of the rituals of Roman emperors and Christian priests even in the early period (Alföldi 1935: 38; Treitinger 1969: 32).

In this context, the emergence of "indexicality" can be understood as a doubly motivated process. On the one hand, both styles of behavior and media of representing the elites, such as oil painting and engraving, proliferated and grew more diverse in the modern era. On the other hand, the noblesse of the modern age increasingly insisted on the anciennity of its forms of representation: everything that counted was to have a certain age. 
In this manner, courtly society created a system of gestures that, so to speak, did not function autonomously but referred to the canonical gestures of Christian iconography. For instance, one did not fully remove one's hat but only had to raise it briefly or only touch the brim slightly, as can be observed in the "chapeau" gesture that derives from courtly etiquette and was preserved by the educated middle class. Accordingly, in acts of courtly reverence of the seventeenth century, one could slightly bend one's leg to refer to something that icons expressed through full genuflection.

\subsection{Symmetric vs. asymmetric bodily signs}

The distinction between symmetry and asymmetry proposed here refers to the level of signifiers, i.e. bodily movements. Symmetrical body movements are executed by each participant of a given interaction either synchronically (e.g. shaking hands, raising arms for an embrace) or with a delay (turn taking) (e.g. exchanging caresses, bowing to one another). Asymmetrical body techniques are only performed by one of the participants of the interaction (e.g. blowing a kiss).

The distinction between symmetry and asymmetry is not identical to the distinction between equality and inequality, which belongs to the level of signifieds (Schürmann 1994: 159 196). Modern society retains constructions aimed at distinguishing between equality and inequality even when, for example, symmetry is enacted on the level of physical contact. A handshake is no longer a sign of equalization today. In the Middle Ages, however, symmetric and asymmetric body techniques served to symbolically indicate socially valid hierarchies. In the context of an estate-based society, the relationship between signifiers and signifieds rested on the principle of similarity and analogy. The vertical stratification of the human body was projected onto social hierarchies, and vice versa.

Symmetrical body techniques thus occurred primarily in diplomatic relations, communication among rulers, as well as in monasteries, as in the example of the ritual kiss of peace (osculum fidei et pacis), during which the monks approached one another symmetrically and aligned their cheeks. In general, however, symmetry was not a part of everyday routine in an estate-based society. Symmetrical uses of the body were analogous to a legally valid process of establishing equal status. When the German King Konrad III (1138 1152) refused to genuflect before the Byzantine Emperor Manuel I "due to the honor of the Roman Empire" (ob honorem Romani imperii), it was demanded that both rulers ride toward one another and exchange kisses on horseback (ut [...] ex parilitate convenientes sedendo se et osculando salutarent) (see Fuhrmann 1993: 127 with reference to Arnold von Lübeck's report in the Chronica Slavorum).

With regard to asymmetrical communication techniques such as bowing to breast level (inclinatio semiplena) or to the ground (ad terram), they were considered to be norm violations in the context of medieval etiquette, since social hierarchies at the time (unlike today) were indicated through symbolic translations into vertical distances between bodies. In acts of obeisance that adhered to the norm, asymmetric gestures of homage could not be lacking (Althoff 1997: 202). One of the most important characteristics of the modern era consisted in its tendency to conceal the explicit semantics of bodily signs and in the decreased expressive force of body positions with regard to social relationships of equality and inequality. The transparency of pre-modern spaces of interaction, in which those who were older, richer, or more powerful were assured deep genuflection, increasingly dissolved between the sixteenth and nineteenth 
centuries. Most often, this process occurred not under pressure from below but, on the contrary, by the initiative of the upper classes. The following resolution by Kaiser Joseph II of January 10, 1787 is indicative of this trend. In it, it was decreed

$[\ldots]$ that henceforth, $[\ldots]$ the kiss on the hand which men and women offer to the highest of lords of the highest archducal house, just like genuflections in reverence and the kneeling before anyone and in all cases is to be ceased entirely, [...] likewise no one, [...] who wishes to request or otherwise petition anything, shall no longer kneel, for this is no fitting action between men, but is to be reserved for God alone. (Schreiner 1990: 128)

Body-related decrees from the eighteenth century illustrate the dissolution of traditional, visually oriented modes of perception in which social hierarchies were projected onto the vertical body axis and depicted by analogy. In the sphere of power, a spatial symbolism of "left" and "right" (the expressions left wing and right wing come from the British Parliament in the 1700s, when the Liberal party sat on the left and the Tory party sat on the right) became established by the eighteenth century, while the symbolism of "above" and "below" in self-representations of powerful political figures increasingly faded into the background. The new politics aimed at concealing inequalities surfaced in the rhetoric of the "universally human". It aimed to block the observation of differences in status and rank on the level of the body.

\section{Areas of application}

The physical behavior that determined the course of most everyday interactions in the Middle Ages, such as prayer, conflict resolution, inviting and receiving, greeting and taking leave, was subject to conscious societal standardization. With regard to medieval bodily practices, we will examine four sets of norms: religious, legal, ceremonial, and etiquette norms.

(i) Norms of transcendental communication (worship) fell under the authority of religious ethics.

(ii) Norms related to murder, incest, theft, and insulting of the ruler, which were essentially based on punitive measures, were codified in the form of laws, carved into stone, and cut into wood.

(iii) Whereas the law was concerned primarily with precedents, i.e. with what had already occurred, ceremonial instructions were anticipatory norms that aimed at preventing the conditions for an unwanted precedent.

(iv) Norms of etiquette, in turn, can be placed into an intermediary zone between ceremonial and courtesy. While ceremonial norms were concerned with observing hierarchies, etiquette norms strove to integrate into the system those who were considered border crossers, such as couriers, messengers, and pilgrims. Anticipatory norms of propriety were (like legal norms) of an idealistic nature. In other words, they were not meant to govern the actions of everyone in every situation.

\subsection{Religion}

The common conception of the Middle Ages as an age of superstition is the result of mistaken interpretations of bodily worship practices, which continue to be viewed as 
demanding an exceptional degree of physical exertion. In fact, the use of the body in medieval religious rites was subject to a strict system of usage rules (adoratio). Aside from worship practices, the signified adoratio also encompassed other forms of transcendental communication, such as those between sacred rulers (i.e. emperors) and their subjects, between artists and patrons, but also between lover and beloved. Ecclesiastic rituals, however, drew on the reverse of the adoratio in the form of expressions of humility.

In the context of physical worship rituals, the signifiers were strictly divided into prostrations (prostrationes), genuflections (genuflexiones), and bows (inclinationes). In the context of antiquity as well as in the medieval tradition, the prostration was most often understood as an extended genuflection. This is particularly true of the position known as genuflexio proclivis, in which the head of the kneeling subject touches the ground. Humbert de Romans (early thirteenth century) treats the prostratio as identical to the genuflexio proclivis. Petrus Cantor (1197) also describes the prostration under the title genuflexiones (see Schmitt 1992: 286). We can infer that the lying body position was viewed as an amplification of the genuflection in liturgical ceremony. In my classification, the term "prostration" only refers to the prostrate position. It is distinct from the genuflection with its various semantic connotations (see Humbert, early thirteenth century: 167).

Even though the classifications of prayer postures conducted in the Middle Ages were based on the knowledge of rituals inherited from antiquity, significant differences from the latter occurred as well. As a pose whose function was restricted to sacral communication, the prostration symbolized primarily an exaggerated fear of God. As the religious prostratio venia, this pose was widely used in the Middle Ages. With regard to the suitability of various body positions for prayer, Petrus Cantor (1197) deemed "most excellent," "most serious," and "most useful" those types of prayer in which "chest, stomach, arms, knees, upper thighs and toes touch the earth" ("Inter omnes autem modos orandi ist est quasi melior et fere utilior: iacere in solo, ita quod os et pectus et venter et brachia et genua nec non et crura atque digiti contingant terram" see Petrus Cantor 1197: 233; see also Trexler 1987: 190 233; Schmitt 1992: 290). In the beginning of the thirteenth century, Humbert de Romans also included the full prostration in his classification of different prayer types. However, he condemned the habit of "certain laymen" to extend their arms in the form of the cross of Christ and to kiss the ground. The rejection may be explained by the association of kissing the ground with pagan practices of earth worship. The prayer instructions of Humbert de Romans and Petrus Cantor show that the liturgical forms of prayer in Catholic prayer practices of the twelfth and thirteenth centuries were treated analogously to rhetorical figurae. Similarly to rhetoric and the art of theatre, the impression of true versus false (e.g. feigned) holiness (ostentatio sanctitatis) depended on the assumption of a certain body posture (eloquentia corporis). Lying prostrate was interpreted as an extreme expression of devoutness in Catholic worship (albeit in a positive sense).

Aside from their concern with technique, twelfth-century prayer manuals consistently distinguish between the space of private and the space of public prayer (Trexler 1987: 43). In this regard, Petrus Cantor refers to certain contemporaries who were "ashamed to pray lying" in public ("[..] dicit $[\ldots]$ verecundor orare $[\ldots]$ in terra prostrates", Petrus Cantor 1197: 838 839). Moreover, the religious semantics of the prostrate position is played off against the use of this technique in court ritual: 
individuals who are accustomed to falling prostrate before a tyrant ought instead to prostrate themselves before God ("Itaque cum prosternas te ante pede alicuius tiranni pro modica pena fugienda, potius teneris te proicere ante deum [...]", Petrus Cantor 1197: 799 802; see also Trexler 1987: 47). Trexler notes: "the opposition of knights to kneeling and especially prostration is today and was even then cited as a cultural characteristic of the medieval West" (Trexler 1987: 47). The symbolism of prayer techniques was used to overcome the controversial ethical attitudes of the armed nobility on the one hand and of a monkhood on the other hand.

Beginning in the late Middle Ages, genuflection with folded hands gained prominence as a competing and more strictly regimented posture during public prayer. In the West, the symbolically generalizing semantics of worship (adoratio) generally applied to genuflexio, and not only to the prostrate position (Bolkestein 1929: 31). In the context of worship, the genuflection was a well-documented phenomenon throughout all of Europe since antiquity. In addition to the prostration, it can be considered the basic element of the genuflecting adoratio technique. It must be noted, however, that Greek "Gods of state," in contrast to later depictions of Christ, were generally not worshipped by genuflection (Bolkestein 1929: 29). The motif of kneeling that appears on ancient Greek vases is associated primarily with female figures. Kneeling girls essentially rested on their heels without inclining their upper body forward (Walter 1910: 244).

The genuflection only gradually established itself in the context of ancient Roman courtly ceremony. Only in the third century did the Christian Church recognize the genuflection before the Roman emperor as a valid ceremony, which in turn led the imperial state to legitimize genuflection in Christian prayer practices (Alföldi 1935: 77). From then on, the practice of genuflection was preserved in particular by those who had attacked it most vigorously during confrontations with Roman emperors: the Christian clergy. This was achieved by means of a reinterpretation of a New Testament passage according to which the Three Holy Kings had worshipped the Infant Jesus on their knees as both God and King. Bishops and priests in particular came to feel included in both state and church hierarchies by the adoratio practice. The history of medieval rule saw many periods during which the pope genuflected before the emperor, or, much more frequently, the emperor genuflected before the pope. Thus Pope Leo III performed the adoratio before Charles the Great (et post laudes ab apostolico more antiquorum principium adoratus est Ann. regni Franc. a. 801). It remains unclear whether the adoratio in this context must be interpreted as full prostration, genuflection, or bowing. In view of the Roman adoratio practices known to us, the use of the prostration (prostratio venia) by the pope before the emperor is rather unlikely. Bowing was a common greeting ritual among free citizens and was thus less appropriate to the context of the adoratio. Genuflection thus appears as the most likely option. Since the coronation of Charles the Great, the proskynesis of the pope before the emperor had not been repeated (see Folz 1964: 175; Kelly 1986: 98). In the late Middle Ages, it was the emperor, however, who was expected to kiss the pope's feet during the coronation ceremony. The year 1209 even saw the introduction of a double foot kiss whenever the pope himself performed the coronation (Wirth 1963: 176; Hoffmann 1990: 44 46).

Prayer and acts of penitence involving repeated prostrations (metanoeae) became almost completely obsolete in Western Catholicism over the course of the twentieth century. By contrast, they continue to be practiced until today on Mount Athos and 
among the Old Believers of the Russian Orthodox Church (Baumgartner 1967: 225). In prayer instructions for Russian Old Believers edited in the late nineteenth and early twentieth century, for instance, prostrations are proscribed for the beginning and end of worship services. Eastern Orthodox instructions for prayer correspondingly give the following suggestions: "When you are to make prostrations do not beat your head against the floor of the church or home. Simply bend your knees and lower your head, but do not strike the ground with it. Move both of your hands away from your heart and properly place them on the floor. Do not extend them like two axes [...]" (Syn cerkovnyj 1894: 25 27; Robson 1995: 49ff.).

\subsection{Law}

The medieval act of jurisdiction comprised both acoustic and gestural aspects of the speech act and was interpreted as a physical act. Since antiquity, the proper connection of physical and verbal expressions in the context of legal eloquence was determined by the rhetorical teaching of actio/pronuntiatio. Instructions on the use of gestures in the context of medieval law can be inferred from the Sachsenspiegel, for instance. The illustrations in this thirteenth-century manuscript served to depict instructive patterns of behavior within the courtroom. Thus, for instance, one illustration depicts the Gaugraf, who invites the Bauermeister (or head of the township, indicated by his straw hat) to speak through a polite hand gesture (his right hand describes an offering movement in the direction of a group of four men). Three Landsassen stand behind the Bauermeister, their hands lowered with palms facing inward in a gesture of reverence and patient expectation. A fourth Landsasse, not quite conscious of his behavior, expresses a negative position (see Die Sprache der Hände: 10). Illustrations such as these served to familiarize plaintiffs with the nature of legal procedures.

Although late Roman rhetoric in its most widespread form generally permitted and approved of the use of hand gestures in the pronuntiatio, it also made allowances for the alternative to the speaking hand. In this context, it was noted that the toga of the ancient Greeks did not feature a pad. Judges and lawyers of the time, whose arms were kept inside the garment, had to resort to another form of gestures. While the clothing of the "old orators" concealed both hands, in later garments one hand remained free for gesticulation. In Quintilian's Institutionis Oratoriae Libri XII (see there 11, 3: 84 124ff.) restrictions on gestures concern primarily the right but not the left hand (manus sinistra), most likely under the assumption that right-handers held the toga with their left hand (Maier-Eichhorn 1989: 114ff.).

The tradition of medieval rhetoric preserved the "hand-out-" and "hand-in-" positions as placeholders for two contradictory meanings, each of which could claim a certain validity. Whereas the first position was viewed as the embodiment of action, the second signified a demonstrative renunciation of action and was thus a symbol of sober-minded self-restraint (Fleckner 1997: 124ff.).

The tendency of medieval judges to conceal their hands in their garments can be gleaned from the works of numerous Baroque authors. In his instruction on the use of rhetorical gestures (Chironomia 1644), for instance, John Bulwer indicated that the hand that was concealed and kept inside the garments was an expression of "modesty" and "frugal pronunciation." This interest in early Christian ethics of modesty found its expression in increased significance of Hellenistic iconography. The statue 
of Aeschines of Macedonia (390 $331 \mathrm{BC}$ ), who is depicted with his hand resting inside his dress, was considered an authoritative example. In his speech against Timarchos, Aeschines invoked the ideal of the public orator of past times, who had addressed the people like Solon with their hands tucked into the folds of their garments. "They were too modest," Aeschines stressed, "to remove their hand from their garments during their speeches" (Aeschines, Against Timarchos: 25).

Not just the act of jurisdiction but every speech act was interpreted as a bodily act in the context of oral culture. The application of legal sanctions rested on a complex system of relationships through which the harm done to the individual body was translated into the degree of damage done. High treason was thus punishable by beheading and theft by cutting off a hand. Even the invalidation of a speech act had a physical dimension. It occurred on a non-verbal level, by means of forced exile, legal censorship of speech, and not least through the removal of one's tongue.

Up until the late eighteenth century, legal sources did not distinguish between bodily versus speech acts in their treatment of cases that led to the tearing or cutting out of the tongue (see Keller [1921] 198; Quanter 1901: 175 178; Schuhmann 1964: 39). Thus, the "illocutionary" power and the "perlocutionary" injury caused by "profane" statements were suppressed directly on the level of the body. Because the word of God was considered as community fostering, the existence of the community was considered threatened by the presence of blasphemy. The increasing standardization of word and sentence semantics within the context of Franciscan and Dominican education helped develop the preconditions for formalizing legal codes, including laws about speech.

The intensification of the punishment for blasphemy (gotzschwür) is highly characteristic for the late Middle Ages and the eve of the Reformation (see Schuhmann 1964: 37). Norm violations due to abusive expressions or curse words directed against God and the saints, or deeds or gestures directed toward holy objects, were punishable by pillory or removal of the tongue, depending on the corresponding legal measure. Furthermore, the cutting out of the tongue was frequently used in the case of other "foul" expressions, such as perjury, and occasionally because of false allegations, libel, and extortion. The tongue was either removed from the throat in its entirety or, as in the sixteenth century in Memmingen, shortened by the width of two thumbs: "Im Jahr 1368 in vigilia Magni wart Heinrich der Schwertfurb [...] gestellt in den branger und darnach wart im die zung uz dem hals geschnitten und die stat ewiglich verboten [...]" ("In the year 1368 in vigilia Magni Heinrich der Schwertfurb was placed onto the pillory, whereafter his tongue was cut from his throat, and he was forever banished from the town." Buff 1877: 166).

The unification of punitive measures demonstrated, for instance, by the Carolina (1532), or Peinliche Halsgerichtsordnung, of Emperor Charles V, encompassed forms of punishment for "criminal" acts of speech that were now increasingly treated in the context of national law: "Abschneidung der zungen Offentlich in branger [Pranger] oder halßeisen gestellt, die zungen abgeschnitten, und darzu biß auf kundtlich erlaubung der oberhandt [Obrigkeit] auß dem landt verwisen werden soll. ("Cutting of tongues: [they are] to be publicly placed on the pillory or into the iron collar, their tongues cut out, and until public permission by the authorities expelled from the land." Cited after Carolina § 198. see Quanter 1901: 176; Hensel 1979: 74).

The transformation of the legal order of Modern Europe was reflected in the increasing value ascribed to conversational rhetoric (Linke 1996: 129). The process by which 
social life became increasingly codified created the background conditions that transformed verbal media into the only possible means of communication and conflict resolution. Whereas the stability of the medieval social order largely rested on acquired body techniques, modernity put greater emphasis on verbal skill, which increasingly dominated society as a technique of information exchange (Fauser 1991: 123). The art of conversation, differentiated from both law and ceremony, became a trans-societal value over the course of the eighteenth century and was even accorded the role of the primary medium in social communication. Christian Thomasius encapsulated this transformation in a single sentence: "The basis of all societies is conversation" (Thomasius 1710: 108).

Close attention to the historical relationship between conversational practices and punishment by removing the tongue, with a particular stress on the interrelation between rhetorical and brute-force mechanisms of blocking speech, shows that the social rhetoric of early modern Europe integrated methods of communication that aimed at cancelling out speech acts into social practices. They enabled the cancelling out of speech acts primarily on the "rhetic" level, by drawing on rhetorical patterns such as the following: "Let's change the subject," "Let's not talk about that now" (Freidhof 1992: 22b).

Early modern conversation manuals propagated polite expressions that, for instance,

(i) contained information about the receptivity of the listener ("I don't want to hear anything about that"); or

(ii) limited the amount of information communicated ("Enough of it," "Let's drop the subject"); or

(iii) led the conversation in a new direction ("Let's talk about something else instead"); or

(iv) imputed to the speaker a pragmatic, or "illocutionary," objective not intended by his conversational move ("You must be joking," "You can’t be serious," "What a question”).

One dialogue in a bilingual conversation manual reads as follows: "Sir, you've put on considerable weight since your marriage" "Surely you are joking!" The form of such dialogues reflects the actual everyday demand for non-violent prohibitions on speech and corrections of speech intentions in frequently recurring conversational situations. In line with Radtke's observation, we must note that most conversation manuals before the early seventeenth century were rather rudimentary. Only in the beginning of the seventeenth century did notable foreign language grammar books begin to be published more frequently. Both the foreign didactic literature used in teaching as well as the basic grammars were designed rather ordinarily in the seventeenth century. These foundations were essentially adopted in the eighteenth century and the basic approaches were retained (Radtke 1994: 48 56).

\subsection{Ceremony}

Ceremony served to symbolically depict and thus stabilize social hierarchies. On the level of signifiers, the ceremonial normativization of behavior focused on bodily (proxemic) distance and asymmetric body techniques such as the bow and the genuflection. 
On the level of signifieds, ceremonial systems of proximity aimed primarily to depict a temporal difference between generations ("older" vs. "younger") as a spatially construed difference ("far" vs. "near"). Each member of a given community was assigned a firm position and a fixed distance vis-à-vis the other within its system of pedigree.

Secondly, ceremonial distance established itself as protective distance in the context of male rulers. A distance of over three meters increased the difficulty of quickly using a bared weapon such as a dagger or sword. Accordingly, as late as the sixteenth century, Western diplomats were led toward Ottoman rulers while being held at both arms ("Die zwen Bassa khamen unnd namen den Grauen [den Grafen Niclas Salm]. Jeglicher bey ainem Armb, unnd füerten den zw dem Khaiser [...]", Herberstein 1517: 334). Beginning in the late seventeenth century, this also became the valid way to approach rulers in the Russian court ("Beym Handkuss wurden wir an die Arme gefasst [...]", Kämpfer [1683] 1827).

Thirdly, ceremonial distance served to depict the asymmetry of social status relationships. The sequence of steps during the approach was usually determined by a unipolar (as opposed to a bipolar) vector, so that only one of the parties could move. As a result, the mutual approach of individuals of higher and lower rank was evaluated in different ways in the case of the former as the right to a patronizing show of mercy; in the latter as the duty to show respect. The same rule of asymmetry was valid both on the nonverbal and on the verbal level.

Fourthly, ceremonial distance was considered a non-dialogical form of representation. Only the higher-ranking party was allowed to abridge the distance, whereas the "gemein man" ("common man") was forced to observe the indicated spatial distance. Those who were accorded a lesser role in the discourse according to their rank were neither allowed to initiate nor to conclude the conversation, nor to freely choose and elaborate the topic. In other words, free movement in the context of the conversation was forbidden. Ceremonial distance consequently served to block the mechanism of interpersonal rhetoric.

The respect quotient of a ceremonial obeisance was indirectly proportional to the extent of verbal communication. Put differently, the less was said during ceremonial acts of reverence, the more momentous the obeisance. As a rule, ceremonial shows of obeisance with sacral semantics were only executed non-verbally. The ceremonial silence that was mandatory in the presence of the Roman emperor was characteristic of such cases. When the emperor approached, silence (silentium) was enforced. The meetings of the emperor's privy council were therefore also referred to as "Silentium." The office of the "Silentiarii" gradually developed into an important state organ. From the point of view of comparative cultural studies, however, it must be noted that ceremonial silence was much more strictly observed at the Byzantine, and later the Muscovite, Court than in the Roman Empire.

Fifthly, ceremonial distance was implemented as a gaze-specific distance that enabled public representations of power to be perceived visually. The possibility of positioning oneself at viewing distance to the ruler was perceived as a sign of privilege in all early- and pre-modern societies. Conversely, in Byzantium, Rome, Vienna, and at the Muscovite Court it was forbidden to turn one's back to the ruler during an audience with the emperor or tsar. Following the rules summarized in the Byzantine ceremonial codex De Ceremoniis Aulae Byzantinae (tenth century), patricians had to back away from the emperor toward the door in reverse (opisthopodeî) following proskynesis, 
so that their face remained turned toward the emperor (De Ceremoniis I: 32; II: 56; Vogt II: 160).

Alföldi's 1935 [1970] studies on the genesis of court ceremony in the West have shown without doubt that rituals such as observing a ceremonial distance to the ruler and performing asymmetrical gestures of obeisance (such as genuflection) slowly emerged within the context of late Roman imperial ceremony. It is symptomatic that the introduction of proskynesis at the court of Diocletian (284 305 AD) occurred against the background of a far-reaching codification of administrative and everyday life. Aside from the submissive genuflection, such standardizing measures included the introduction of a uniform trade tax, the subdivision of sovereign territory, the introduction of price regulation, the standardization of coinage, and finally the far-reaching bureaucratization of the administrative apparatus. "Principate" was replaced by "Dominate" and henceforth the Emperor expected to be honored as Dominus rather than as the Princeps among equals.

It was as late as the third century $\mathrm{AD}$ that genuflection gained entrance into the system of government of late antiquity, and later that of the Middle Ages. Diocletian, who ruled from 284 to $305 \mathrm{AD}$, may have been the first emperor to firmly incorporate it as part of court ritual. Quite symptomatically, one of the most important preconditions for this was the decline of the greeting rituals exchanged between the emperor and his senators, which involved a mutual kiss and emphasized equality. Even Tiberius (14 37 AD) already replaced the daily receptions in the early morning with the simultaneous arrival of all council members, apparently because of administrative concerns. During this transition, the "day-to-day kisses" (cotidiana oscula) were also abolished as the epitome of salutatio, which had the effect of increasingly subjecting greetings to the control of state authorities (Alföldi 1935: 41).

Henceforth the genuflection (genuflexio) became the epitome of imperial ceremony. Emperor and king kneeled during the unction, vassals kneeled during commendation and obeisance, and knights kneeled while being knighted (see Amira 1943). Aside from the common distinction between falling on one knee (simplex) and on both knees (duplex), the question as to whether one should kneel with erect or lowered upper body continued to lead to disagreements. In the first version (genuflexio recta), the upper body was aligned orthogonally to the axis of the knee. In the second variant (genuflexio proclivis) the upper body of the kneeling subject was inclined forward toward the ground. The resulting inclined angle was often so large that the head touched the ground, as was the case in the Chinese kau-tau and most likely in the Russian "bowing down" (čelobitie) (see Sittl 1890: 160). Western rules for the knave and page service, for instance, proscribed kneeling on one knee before every lord, "whoever he may be" "Hold up youre hede, and knele but on oone kne // To youre sovereyne or lorde, whedir he be" (The Babees Book V. 62ff., cited after Mahr 1911: 18). In contrast to Western courts, at the Moscow court of the seventeenth century it was customary for the head to touch the ground during the adoration of the Tsar. (According to reports of the time, Muscovite diplomats during a reception on October 101654 "each time bowed with their foreheads down to the ground", "sich idesmalhs mit der stirn gantz auff die erden geneigt." This form of reverence was accordingly titled "reverence in the Muscovite manner", "die reverentz auff die moscowitische arth").

While the genuflection became a part of papal and imperial ritual in the early Middle Ages, use of the foot kiss generally remained restricted to acts of homage before the 
pope (Schreiner 1990: 118). Due to the resistance of the West European knighthood and West European kings, the foot kiss was rarely used as a ritual of paying obeisance to the ruler in the West Roman Empire. In the few extant references to it, this gesture only appears as an act of submission: thus the knights of Milan kissed the feet of Barbarossa in 1182. In the East Roman Empire, however, the foot kiss was practiced regularly during acts of obeisance to the emperor and the patriarch. It is likely that the Roman popes adopted the foot kiss based on Byzantine court ritual, since, beginning in the seventh century, the deacons who read the gospels during the papal mass approached the throne after reading in order to kiss the pope's feet. In the context of papal elections, too, both ecclesiastic and secular laymen kissed the feet of the newly elected head of the church.

According to Schreiner, the earliest documents that prove beyond a doubt that even high-ranking secular persons in the West kissed the Pope's feet date to the ninth century. However, the foot kiss was not promoted to an obligatory part of imperial crowning ceremonial until the beginning of the twelfth century. For instance, during the procession leading up to the coronation on February 12th 1111, Heinrich V kissed the feet of Paschalis II, who was waiting before the gates of St. Peter. Papal demands for the foot kiss ritual were often justified by references to biblical role models, but primarily through Christological associations. (See Ps 3, 11: Request to kiss God's feet; Lk 7, 38; 45: Mary Magdalene kissing the feet of Christ; Mt 28, 9: Proskynesis of the women before the risen Christ; Apg 10, 25: the Centurion Cornelius kissing the feet of St. Peter, Schreiner 1989: 1063.)

Aside from the foot kiss, a number of other foot-centered acts of obeisance hovered near the boundary of the allowed and the reasonable. These, for instance, included the washing of feet and the so-called "strator service" performed at the stirrups. In the twelfth and thirteenth centuries, a rivalry arose in the symbolical territory of corresponding rituals of obeisance between the papal and princely powers in the West. As a consequence, since the Middle Ages foot-related obeisance gestures corresponded far more closely than the genuflection to a "border of degradation," the transgression of which could cause irreversible damage to the self-perception of those involved. Such gestures presumably presupposed a well-calculated mutual understanding between the environment and those affected and were mandated primarily in the context of national law and rituals of legal ratification.

In all likelihood, the manner of execution of the foot kiss, the washing of the feet, and the strator service was never completely spontaneous. Most likely, the "script" was always agreed upon in advance by both communicating parties (Ostrogorsky 1935: 200). But even a provisional agreement could hardly ensure the full predictability of the ritual cases where the subject in the lower position used the possibility to diverge into a ritual of evasion. For example, King Frederick Barbarossa's refusal to provide Pope Hadrian IV his services as stableman (1115) was almost certainly a diplomatic trap for which the pope was not prepared. He responded to the king's unwillingness to hold the stirrups by refusing him the kiss of peace. The damaged frame of communication had to be repaired by means of a corrective exchange, until the King finally assented to perform the strator service in the form of a simple ceremony. The ritual of kissing the feet, which consisted of a ceremonial approach on horseback, followed by descending, kneeling, and kissing the feet, therefore generally presupposed the "script-safe" behavior of the involved parties. Apparently, decisions about details of staging were less 
the responsibility of the emperor or the pope than of the masters of ceremony, who, among other things, were to ensure an illusion of spontaneity and veracity. Such is the impression conjured by the description of a foot kiss ritual in 1177, performed by the newly crowned King Frederick I Barbarossa before Pope Alexander III:

Frederick approached the Pope, removed his red robe, threw himself onto the ground before Alexander with arms stretched apart, kissed his feet ["like the first of the apostles" deos culatus eius tanquam primi apostolorum pedibus] and then his knees. Touched to tears, the pope rose slightly, helped the emperor stand up, embraced his head with both hands, gave him the kiss of peace [pacis osculum] and bade him sit by his side. (Althoff 1997: 229 258)

As stylized eyewitness report shows, the aim of the foot kiss was less to indicate real positions of secular and ecclesiastical power than to elicit assertions about the legitimacy of a ruler's sovereignty from the audience. Ultimately, this approach served to reveal the channels of communication between primary and secondary social elites. Correspondingly, the foot kiss offered to the pope by the emperor was justified in various ways by contemporary opinion: on the one hand, it was viewed as a simple ceremony, on the other, as one of the acts of reverence befitting the first apostles, and thirdly, as an act of obeisance due only to God. Explanations for the rationale behind Barbarossa's gesture vary from source to source. According to Bosso, the emperor performed the foot kiss "according to the model of the first of the apostles," i.e. Saint Peter. According to Romuald, the gesture was directed exclusively at God (Deum in Alexandro venerans). According to the annals of Pisa, Barbarossa offered due reverence to his spiritual father (li fece debita reverenzia come a Padre spirituale) (see Hack 1999: 654). Based on the thesis that in most documented cases the function of the foot kiss ritual was ostentatious and directed toward the medieval urban public, we can assume that the termination of this ritual (with the last papal coronation, that of Charles V in Bologna, 1530) was sanctioned less by its participants than by the audience.

The intensive reformatory polemics against the kissing of the pope's feet coincided with a tendency to raise the middle-class body and to reduce the physical strain of obeisance rituals. In his Tractatus de Ecclesia, Jan Hus characterized the foot kiss demanded by the popes as an expression of anti-Christian conceit. The heresies of which Hus was accused during the Council of Constance (1414 1418) also included his notion that the pope merited neither the title sanctissimus nor the foot kiss. In the year 1468, Emperor Frederick III refused to kiss the feet of Pope Paul II because otherwise he "might not have preserved the majesty of the empire." Furthermore, Martin Luther's 1520 treatise "to the Christian nobility of the German nation" condemned the "Fußkussen des Bapsts" ("kissing of the pope's feet") as "Endchristlich exempel" ("an anti-Christian example") (see Hus 1413: 98; Schreiner 1990: 123 124ff.). The tendency toward obscuring ostentatious gestures, which also manifested itself in secret state policies and the clothing habits of the Jesuits, suggested that the faith of both the Catholic Church and secular power in iconic depictions of canonical devotional gestures had lessened significantly toward the mid-sixteenth century.

\subsection{Etiquette}

In the Middle Ages, etiquette was applied in situations where the boundaries of different social systems had been crossed. This was the case with migrants, such as couriers 
and pilgrims, which travelled from land to land. The necessity of implicating such border crossers in a foreign system of relationships led to a series of conversion mechanisms that enabled a partial equalization of insiders and outsiders.

In the following, I suggest a distinction among three types of equalization: equalization in the sense of leveling, equalization in the sense of ritual inclusion, and equalization in the sense of identical means of exchange.

The first aspect, leveling, refers to a symbolic inversion of social hierarchies of power. Most medieval leveling rituals, such as the washing of feet, occurred primarily in monasteries, but spread from there into secular space in the form of Christological rituals. A specific example of leveling in governmental greeting rituals is the exemption of subjects from genuflection, i.e. by raising the supplicants from the ground (allevatio supplicis). The increasing tendency toward social leveling in public bodily practices was characterized by the desemanticization of greeting and parting phrases that stress status. This is the case in the German servus (Latin 'the slave') and the Italian ciao, which derives from schiavo (likewise 'the slave') (see Prati 1936: 240ff.).

The second aspect of the notion of equality encompasses the semantics of inclusion. In most traditional cultures, the latter corresponds to a symbolic restoration of primordial kinship relations, such as by ritual "fraternization." In such cases, "equality" is established by force of belonging to the same extended family or community of Christian believers. This process is exemplified by the fraternal kiss of peace, the so-called osculum fidei et pacis, which was characteristic for medieval peace agreements. In societies where communicative accessibility was reserved for a few houses of nobility related through marriage, the symbols of "primordial" relationship generally had legal status. They therefore guaranteed the preservation of social boundaries (Voss 1987: 134 136). The treatment of the excommunicated in the Middle Ages shows that the socalled "brotherly kiss" was also considered as a sign of inclusion. In addition to the kiss of peace, excommunicated subjects were to be refused company at the table, polite address, greeting words, as well as conversation ("In quinque maxime vitandi sunt excommunicati, videlicet in mensa, oratione, salutatione osculo pacis et in colloquio" Summa de Confessione des Petrus von Poitiers, around 1200, cited after Fuhrmann 1993: 118).

The third aspect of equalization implies the identity of the rules of the game and the means of exchange, and thus presupposes the notion of communication as an exchange. One example of this phenomenon is the English "handshake."

Ritualized inclusion into the family was among the preferred forms of equalization in the Middle Ages. Only in modern Europe did the unification of means of exchange become of greater importance. Documents prove that in the Middle Ages the kiss of peace and the fraternal kiss (osculum pacis) were exchanged between strangers (see Strätz 1999: 1590ff.). But outside of the church, too, it was typical for "community members to exchange the fraternal kiss after communal prayer and before the beginning of the Eucharistic part of the mass" (Schreiner 1990: 101ff.). According to popular belief, the ritual of the fraternal kiss can be traced to a rule that the Apostle Paul imparted to the faithful: "Greet one another with the holy kiss [Salutate invicem in osculo sancto]" (This is nearly a fixed expression in the letters of St. Paul. St. Paul, Rome 16, 16; I. Cor. 16, 20, II. Cor. 13, 12; I. Thess. 5, 26 here: invicem fratres omnes) (see Voss 1987: 139). It is also very likely, however, that the legal-protocolary symbolic power with which this kiss was vested not only in the normativized ecclesiastic space 
of communication in the Middle Ages, resulted from the nature of pre-modern societies. In the latter, social boundaries were determined not by formal organizations, but primarily by sensorily perceptible interactions in the context of exchanging gifts. One can even assume with great likelihood that medieval princely law served as an essential precondition for the spread of this ecclesiastic gesture. In the context of the fraternal cheek kiss, we can refer to the law of the "family of kings," according to which the members of the ruling family were required to address each other using the brotherly "you" ("Du") and to kiss. Dölger indicates "that the kiss between kings was a well-known institution in the Middle Ages" (Dölger 1976: 34 69). In the meeting of kings in Ruodlieb, which largely reflects eleventh century ceremonial, according to Voss, the use of the kiss as a greeting between rulers is also entirely taken for granted (Voss 1987: 142). A typical example of later exchanges was the meeting between Heinrich VI and Philipp II in Milan (1191), where the German emperor received the French ruler in osculo pacis (Voss 1987: 139). This form of greeting by kiss is also documented in the context of East- and West-Franconian encounters, such as in the meetings between Otto II and Lothar (in 980), who kissed simultaneously as family members and as rulers (osculum sibi dederunt).

The reception by kiss and embrace became a firm component of knightly and diplomatic encounters in the late thirteenth century. In contemporary literature, the great significance of "brotherliness" is expressed in greeting scenes of a highly emotional nature. We must distinguish, however, between the greeting kiss exchanged while standing and the expressions of obeisance that took place between sovereign and vassal during feudal transactions. Mentions of physical contact between vassal and sovereign disappear from the records around the end of the sixteenth century. According to Old French law, the vassal kneeled and placed his hands into the hands of the sovereign (immixio manuum), upon which the latter raised the vassal from his knees and kissed him on the mouth (see Chénon 1924: 137). On the verbal level, ritualized formulas affirmed the semantics of mutual trust during feudal transactions (see "Vers 1260, Le Livre de jostice et de plet décrit le rite de l'hommage en ces termes: Cil qui requiert doit joindre les mains et dire: Sire, ge deviens vostre home, etc [...] Et li sires doit respondre: Et ge vos recef à home, que ge foi vous porterai, comme à mon home, et vos en bese en nom de foi" cited after Chénon 1924: 138). Such encounters involved not only the cheek kiss, but kisses on eyes and lips as well. "Plus de c[ent] fois li baise // et la bouche et le nez" (cited after Schultz 1889: 521). See also the same document in Heckendorn (1970: 3). For instance, after Hartmann von Aue's Gawein and Iwein recognized one another they kissed each other on eyes, cheeks, and mouth for many hours. See: "Si underkusten tausentstunt // Ougen wangen unde munt" (Hartmann von Aue, Iwein, V. 7503/4). On this, see also Heckendorn (1970: 3ff). See also the following commentary by Schreiner: "The writers of Middle High German lyric and epic poetry profited from the fact that 'munt' and 'stunt' rhymed. Apparently there was no shortage of lovers who kissed the eyes, cheeks, and mouth of their beloved 'tusent-stunt', 'dusent stund' or 'tausend stunt, êtlicher stunt, an der stunt, bî der stunt' and 'zô der stunt'" (Schreiner 1990: 104; see also Jones 1966: 195 210). In Wolfram von Eschenbach's Parzival, Gahmuret kisses his knights in greeting: "Dô kuste er die getriuwen [...]" (Wolfram von Eschenbach Parzival II: 99; V: 7).

Aside from male greeting rituals, medieval literature contains numerous scenes in which the maid-of-honor responds to the greeting of the knight with a kiss on the 
cheek. In the Middle Ages, this gesture was presumably not entirely free from the possible erotic connotations of courtly love (see the scene depicting the greeting of the cousin of Gahmuret, during which the queen kisses the knight's dagger: "von der küneginne rîch // si kuste den degen minneclîch") (Wolfram von Eschenbach Parzival I: 47; V: $28 ; 29 ; 30 ; 48 ; \mathrm{V}: 1 ; 2)$. It must be added, however, that non-erotic symbols, such as collective feasts and the giving of alms, could also occur in a ritualized relationship to the female kiss. According to the notions of pre-modern economics, the female greeting kiss was thus associated less with eroticism and more with ritualized acceptance into an extended family.

In this function, the lady's kiss was incorporated into the sign system of medieval ars donandi: it symbolized the wealth and military might of the feudal lord and implicitly referred to his reproductive ability. Most often, the lord invited his male guests to be greeted with a kiss by his wife. Accordingly, medieval poetry tended to raise the female kiss to the equivalent of payment for knightly virtues. In the context of the dominant symbolic order of medieval society, the knight's ascent along the social ladder was usually depicted symbolically by shortening the ceremonial distance vis-à-vis the sovereign. In Wolfram von Eschenbach's Parzival, Gahmuret, victorious against Razalic, requests that the latter approach and kiss his wife: "gêt näher, mîn hêr Razalic: // ir sult küssen mîn wîp" (Wolfram von Eschenbach Parzival I: 46; V: 1, 2; Heckendorn 1970: 3ff). In the work of an anonymous Rhenish poet (around 1180), the queen steps out of the women's chambers (the bower) in order to approach the knights of King Rother and to kiss them ("die vrouwe alsô lossam // kuste den hêren // do schiet her danne mit êren // ûz van der kemenâte [...] die konigîn ginc umbe // unde kuste besunder // alle Rôtheres man" König Rother around 1180). And when Parzival meets his teacher's daughter, he is likewise permitted to approach in a rather symbolic manner, whereby "he kissed her on the mouth" ("kuste er sie an den munt") (Wolfram von Eschenbach Parzival III: 176; V: 9; Heckendorn 1970: 3ff).

In the modern era, the integration of feudal economic units into the relationship between absolutist courts and the dissolution of knightly familial ties led to a reevaluation of fraternal greeting rights during court rituals. A tendency toward the semantic relativization of the fraternal kiss in the ecclesiastic context developed at the same time as this gesture was gradually displaced from the secular stage. The significance of the kissing ritual, in effect considered inscrutable, was increasingly undermined by questions about its meaning, i.e. by questions about the extent to which a holy kiss (osculum sanctum) could be distinguished from a sinful kiss between lovers (Hieronymus Epistolae 22: 16; see also Fuhrmann 1993: 117ff.; Sittl 1890: 79). The kiss of peace was increasingly abandoned in the interest of preserving one's image. The early twelfth century saw the propagation of a rule according to which the kiss of peace could be exchanged only within a given house of nobility. Such restrictions on public exchanges of kisses on the mouth may also have been indirectly related to the appearance of the so-called "kissing plaque" (osculatorium or instrumentum pacis). It was now no longer necessary to exchange kisses; "symbolic mediacy was replaced by a consecrated device" (Schreiner 1990: 101). This was a small plate made of medal or marble that featured the image of Christ, which was to be kissed. The osculatorium began to fulfill a symbolic function in church ritual by representing the lips of the community members that were to be kissed. 
Aside from this process of displacement, devotional literature of the early modern period reveals an increasing tendency to differentiate among various meanings of the kiss. For instance, Johannes von Paltz (died 1511) distinguishes between three forms of the osculum corporale: a kiss that can be recommended (osculum commendabile), a kiss that can be excused (osculum excusabile), and a kiss that must be treated with disdain (osculum detestabile). The greeting kiss (osculum receptionis) belongs to the recommended gestures, insofar as it appears justified by Old Testament examples. The osculum cognationis is a forgivable kiss, which takes place between mother and son. Contemptible kisses include those which express affectation (simulatio), treachery (dolositas), and sensual desire (libido) (Johannes von Paltz around 1500: 155 157; cited after Schreiner 1990: 110).

In the early modern period, the handshake replaced the kiss of peace as sign of egalitarian treatment. The increasing popularity of the handshake for initiating communication must be viewed in the context of the general expansion of early modern communicative intercourse, where encounters with strangers and the process of initiation communication were increasingly normativized and formalized. This process of normativization was apparently set off by the fact that individual persons merchants and ambassadors, migratory knights and religious missionaries were increasingly lifted from the context of primordial and ceremonial power hierarchies. Prior to a tournament, knights who did not know each other greeted one another by lifting their visor and showing an unprotected right hand regardless of status and rank. The primary focus of the event was on comparing their performance. Quite symptomatically, one symbol of honor consisted in exchanging positions as well as weapons with the opponent. In a similar way, the use of the handshake as a greeting among merchants served to affirm the equality of communicative strategies outside their range of application within power hierarchies (Mahr 1911: 41).

While extending the right hand in greeting was primarily the privilege of feudal lords and their progeny in the early Middle Ages, sixteenth century diplomatic protocols indicate that this gesture, at least in England, had already become a component of diplomatic greeting rituals. As early as in the work of Saxo Grammaticus, we read, according to Kolb, about the encounter between Frederick I and Waldemar in Lübeck (1181), which included an embrace, a kiss, and a handshake ["Siquidem inprimis eum amplexu atque osculo decentissime veneratus, mox dextra honorabiliter apprehensa"] (Kolb 1988: 99). Apparently, shaking the right hand was part and parcel of greeting rituals in encounters between rulers both in the early and late Middle Ages. In this regard, Voss (1987) polemicizes with Wielers (1959), who argues that the use of the term dextras dare in the context of meetings between rulers could only be traced to the eighth century (Voss 1987: 139ff.).

The frequency with which diplomatic correspondence since the late sixteenth century mentions the hand greeting in the context of diplomatic meetings suggests that emblematic gestures at the time became abstracted from their concrete semantics of approach, affirmation, and peaceful intentions, and were increasingly formalized. As a result of this formalization of diplomatic practice, offering one's hand became a simple signal for initiating communication. In this form, it continues to be used regularly at the beginning of conversations, regardless of the ranks of the interlocutors, and even in cases where the conversation concerns a disagreement of conflict of interests. 


\section{References}

Aeschines 1908. Aeschinis Orationes. Leipzig: Teubner. First published [400 AD].

Alfoldi, Andreas 1970. Die Monarchische Reprasentation im Romischen Kaiserreiche. Darmstadt, Germany: Wissenschaftliche Buchgesellschaft. First published [1935].

Althoff, Gerd 1997. Spielregeln der Politik im Mittelalter. Kommunikation in Frieden und Fehde. Darmstadt: Wissenschaftliche Buchgesellschaft.

Amira, Karl von 1905. Die Handgebarden in den Bilderhandschriften des Sachsenspiegels. Munich: Akademie der Wissenschaft.

Bolkestein, Hendrik 1979. Theophrastos' Charakter der Deisidaimonia als Religionsgeschichtliche Urkunde. Religionsgeschichtliche Versuche und Vorarbeiten 21(2): 1 21. Giessen: Topelmann. First published [1929].

Buff, Adolf 1877. Verbrechen und Verbrecher zu Augsburg in der zweiten Halfte des 14. Jahrhun derts. Zeitschrift des Historischen Vereins fur Schwaben und Neuburg 4(2): 1108.

Chénon, Emile 1924. Le rôle juridique de l'osculum dans l'ancien droit français. Mémoires de la Société des Antiquitaires de France Serie 8, Volume 6, 124155.

Dolger, Franz 1976. Die "Familie der Konige" im Mittelalter. In: Franz Dolger, Byzanz und die Europaische Staatenwelt, 34 69. Darmstadt: Wissenschaftliche Buchgesellschaft.

Fauser, Markus 1991. Rhetorik und Umgang. Topik des Gesprachs im 18. Jahrhundert. In: Alain Montandon (ed.), Uber die Deutsche Hoflichkeit: Entwicklung der Kommunikationsvorstellun gen in den Schriften uber Umgangsformen in den Deutschsprachigen Landern, 117 143. Char lottesville: University of Virginia Press.

Fleckner, Uwe 1997. Napoleons Hand in der Weste: Von der ethischen zur politischen Rhetorik einer Geste. Daidalos 64: 122129.

Folz, Robert 1964. Le Couronnement Impérial de Charlemagne: 25 Décembre 800. Paris: Gallimard.

Freidhof, Gerd 1992. Typen dialogischer Koharenz und Illokutions Blockade. Zeitschrift fur Sla wistik 37(2): 215230.

Fuhrmann, Horst 1993. Willkommen und Abschied. Uber die Begrußungs und Abschiedsrituale im Mittelalter. In: Wilfried Hartmann (ed.), Mittelalter. Annaherungen an eine Fremde Zeit, 111 139. Regensburg: Schriftenreihe der Universitat Regensburg.

Hack, Achim Thomas 1999. Das Empfangszeremoniell bei Mittelalterlichen Papst Kaiser Treffen. Vienna: Bohlau.

Heckendorn, Heinrich 1970. Wandel des Anstandes im Franzosischen und Deutschen Sprachgebiet. Basel: Lang.

Hensel, Gerd 1979. Geschichte des Grauens. Deutscher Strafvollzug in 7 Jahrhunderten. Altendorf: Lector Verlag.

Herberstein, Sigmund 1855. Selbstbiographie Sigmunds Freiherrn von Herberstein. In: Theodor von Karajan (ed.), Fontes Rerum Austriacarum, Abt. 1, Volume 1, 67 396. Vienna: Bohlau. First published [1517].

Hoffmann, Thomas 1990. Knien vor dem Thron und Altar. Friedrich Nicolai und die Orthopadie des aufrechten Ganges vor den Kirchenfursten. In: Bernd J. Warneken (ed.), Der Aufrechte Gang. Zur Symbolik einer Korperhaltung, 42 49. Tubingen: Tubinger Vereinigung fur Volkskunde.

Hus, Jan 1413. Tractatus de ecclesia. Edited by Samuel Harrison Thomson. Cambridge: Roger Dymmok, 1956.

Jones, George Fenwick 1966. The kiss in Middle High German literature. Studia Neophilologica 38: 195210.

Kampfer, Engelbert 1827. Diarium Itineris ad Aulam Muscoviticam indeque Astracanum suscepti Anno 1683. Edited by Friedrich Adelung. [First published in 1683]. Saint Petersburg.

Keller, Albrecht [1921] Der Strafrichter in der Deutschen Geschichte. Bonn/Leipzig: Nachdruck Hildesheim.

Kelly, John Norman Davidson 1986. The Oxford Dictionary of Popes. Oxford: Oxford University Press. 
Kolb, Werner 1988. Herrscherbegegnungen im Mittelalter. Bern: Lang.

Linke, Angelika 1996. Sprachkultur und Burgertum. Zur Mentalitatsgeschichte des 19. Jahrhun derts. Stuttgart: Metzler.

Loenhoff, Jens 2001. Die Kommunikative Funktion der Sinne: Theoretische Studien zum Verhaltnis von Kommunikation, Wahrnehmung und Bewegung. Konstanz: UVK Verlagsgesellschaft.

Mahr, August 1911. Formen und Formeln der Begrußung in gebruder knauer England von der Nor mannischen Eroberung bis zur Mitte des 15. Jahrhunderts. Heidelberg: Lang.

Maier Eichhorn, Ursula 1989. Die Gestikulation in Quintilians Rhetorik. Bern: Lang.

McLuhan, Marshall 1960. Five sovereign fingers taxed the breath. In: Edmund Carpenter and Marshall McLuhan (eds.), Explorations in Communication: An Anthology, 207 208. Boston: Beacon Press.

Ong, Walter J. 1982. Orality and Literacy. The Technologizing of the Word. London: Methuen.

Ostrogorsky, Georgije 1935. Zum Stratordienst des Herrschers in der byzantinisch slawischen Welt. Seminarium Kondakovium: Recueil d'études (Archéologie, histoire de l'art, études by zantines) 7: 187204.

Paltz, Johannes von 1983. Coelifodina. In: Christoph Burger (ed.), Werke 1, Spatmittelalter und Refor mation. Texte und Untersuchungen 2, 155 157. Berlin: Heiko A. Oberman. First published [1500].

Petrus Cantor [1197] 1987. De oratione et speciebus illibus. In: Richard Trexler (ed.) The Christian at Prayer. An Illustrated Prayer Manual Attributed to Peter the Chanter, 165235. Binghampton, NY: Medieval and Renaissance Texts and Studies.

Prati, A. 1936. Nomie supranommi die genti indicanti qualitàe mestieri, In: Archivum Romani cism, Bd. 20, 200256.

Quanter, Rudolf 1901. Die Schand und Ehrenstrafen in der Deutschen Rechtspflege. Eine Krimi nalistische Studie. Dresden: Aalen.

Radtke, Edgard 1994. Gesprochenes Franzosisch und Spachgeschichte. Tubingen: Niemeyer.

Reiske, Johann Jacob (ed.) 17511766 Constantini Porphyrogeniti Imperatoris De Ceremoniis Aulae Byzantinae Libri Duo. Graece et latine e Recensione Io. Leipzig. [Reprinted 1829: Bonn, Weber].

Robson, Roy R. 1995. Old Believers in Modern Russia. DeKalb: Northern Illinois University Press.

Romans, Humbert von 1888 1889. Expositio super constitutiones fratrum praedicatorum. In: Joachim Joseph Berthier (ed.), Opera Omnia, Volume 2, 160 167. Stuttgart: Klett Cotta. [cited by Schmitt 1992: 286ff.]

Schmitt, Jean Claude 1992. Die Logik der Gesten im Europaischen Mittelalter. Translated by Rolf Schubert and Bodo Schulze. Stuttgart: Klett Cotta.

Schneider Brakel, Franz and Jurgen W. Braun 2005. Die Sprache der Hande. Mainz: Schmidt.

Schreiner, Klaus 1990. Er kusse mich mit dem Kuss seines Mundes (Osculetur me osculo oris sui, Cant.1, 2). Metaphorik, kommunikative und herrschaftliche Funktion einer symbolischen Han dlung. In: Hedda Ragotzky and Horst Wenzel (eds.), Hofische Reprasentation. Das Zeremoniell und die Zeichen, 89 132. Tubingen: Niemeyer.

Schuhmann, Helmut 1964. Der Strafrichter. Seine Gestalt seine Funktion. Kempten: Verlag fur Heimatpflege.

Schultz, Alwin 1889. Das Hofische Leben zur Zeit der Minnesinger. Leipzig: Zeller.

Schurmann, Thomas 1994. Tisch und Grußsitten im Zivilisationsprozess. Munster: Waxmann.

Sittl, Karl 1890. Die Gebarden der Griechen und Romer. Leipzig, Germany: Teubner.

Stratz, Hans Wolfgang 1999. Kuss. In: Robert Henri Bautier (ed.), Lexikon des Mittelalters, Vol ume 5, 1590 1592. Stuttgart: Metzler.

Syn cerkovnyj 1894 Сын церковный 1894 . Москва: Типография единоверцев.

The Babee's Book end of the 1500s (including: Urbanitas, the Young Chidren's Book, the Lytylle Childrenes Lytil Book, Hugh Rhoder's Boke of Nurture, John Russell's Book of Nurture, The Boke of Kervynge, The of Curtasye, Symone's Lesson of Wysedome for all Maner Chyldren). London. [reprinted 1868].

Thomasius, Christ 1710. Kurtzer Entwurff der Politischen Klugheit, Sich Selbst und Andern in allen Menschlichen Gesellschafften Wohl zu Rathen und zu einer Gescheiden Conduite zu Gelangen. Frankfurt/Leipzig: Athenaum. [Reprinted 1971: Frankfurt am Main]. 
Treitinger, Otto 1969. Die Ostromische Kaiser und Reichsidee nach ihrer Gestaltung im Hofischen Zeremoniell. Vom Ostromischen Staats und Reichsgedanken. Bad Homburg: Gentner.

Trexler, Richard 1987. The Christian at Prayer. An Illustrated Prayer Manual Attributed to Peter the Chanter (d. 1197). Binghampton, NY: Medieval and Renaissance Texts and Studies.

Viller, Marcel, Ferdinand Cavallera, Joseph de Guibert, André Rayez and Charles Baumgartner (eds.) 1967. Dictionnaire de Spiritualité Ascétique et Mystique. Doctrine et Histoire. Paris: Gabriel Beauclesne.

Voss, Ingrid 1987. Herrschertreffen im Fruhen und Hohen Mittelalter. (Beihefte zum Archiv fur Kulturgeschichte 26.) Cologne: Bohlau.

Vogt, Albert (ed.) 1939 1967. De Ceremoniis, T. 1, Livre 1, chapitres 1 46(37). Paris: Les Belles Letters.

Vogt, Albert (ed.) 1939 1967. De Ceremoniis, T. 1, Livre 1, chapitres 47(38) 92(83). Paris: Les Belles Letters.

Walter, Otto 1910. Kniende Adoranten auf attischen Reliefs. Jahreshefte des Osterreichischen Archaologischen Instituts in Wien 13: 229 244. Vienna: Rohrer.

Wielers, Margret 1959. Zwischenstaatliche Beziehungen im Fruhen Mittelalter. Ph.D. dissertation. Munich.

Wirth, Karl August 1963. Imperator Pedes Papae deosculator. Ein Beitrag zur Bildkunst des 16. Jahrhunderts. In: Hans Martin Freiherr von Erffa and Elisabeth Herget (eds.), Festschrift fur Harald Keller zum 60. Geburtstag. Darmstadt: Roether.

Wolfram von Eschenbach 1952. Parzival. Edited by Karl Lachmann. Berlin: Walter de Gruyter. [First published in the 1300s].

Dmitri Zakharine, Konstanz (Germany) 